\title{
THE NATURAL RESOURCES POTENTIAL AND PECULARITIES OF THEIR EXPLOITATION IN MOUTAINOUS REGIONS (THE CASE OF KVEMO RACHA, GEORGIA)
}

\author{
Elene Salukvadze $^{1 *}$, Tamila Chaladze ${ }^{1}, K_{\text {Ketevan Gogidze }}^{1}$
}

\begin{abstract}
To reveal natural resources of a region it is causally necessary to reveal and describe certain landscapes as far as they are means of manifesting natural resources. Besides they are subject of study of land management. It is important to identify resource potential and current state of landscapes and each of their components. Landscapes occupy certain areas which are characterized with certain natural conditions and, obviously, different natural potential. To study the above issues, we selected mountainous region of Kvemo Racha (Ambrolauri Municipality of Georgia). For the studies, together with literary material and different sources, we used cartographic material, the landscape maps $(1970,1983)$ and the topographic map (scale; 1:50000) of Georgia and Transcaucasia and the observation materials of the field expedition made in 2019 in Kvemo Racha. We constructed a large-scale landscape map for Kvemo Racha (Ambrolauri Municipality) by GIS (geographic information system) technology. The work describes individual natural components of landscapes and resource potential of the distinguished landscapes. The data on mineral resources, climate and agro-climate, soil and forest resources are given in the table and diagrams. Among the landscapes distinguished as a result of comprehensive studies, the landscapes in the Racha Depression on the right and left banks of the river Rioni have especially great potential. These landscapes are located on either sides of the Rioni river gorge, though the landscape on the right bank of the river is especially distinguished. This is Racha Depression with a synclinal river gorge, river terraces, juts at some places, humus-carbonate soils. It is a specific micro-zone on the southern slope of the Lechkhumi Ridge (450-750 m above sea level), with unique vine species (Aleksandrouli, Mujuretuli, Shavi (black) Kapistoni), which are used to produce naturally sweet and semisweet "Khvanchkara" type red wines known world-wide. The wealth of Racha - forest landscapes are also noteworthy as some of them have industrial, others have recreational and ecological resources and are of high significance for preserving the biodiversity in the region.
\end{abstract}

Keywords: Natural - resources potential, Mountainous Regions, Kvemo Racha

\section{The main part}

Kvemo Racha presented as Ambrolauri Municipality, is a region distinguished for its diversity in nature (like the whole region of Racha).

Ambrolauri Municipality (1 town and 68 villages) is located in Western Georgia on the south-eastern slopes of the Caucasus Mountains, in the Rioni river basin, bordered on the west by Tsageri and on the north by Lentekhi municipalities, on the east by Oni municipality,

\footnotetext{
${ }^{1}$ Vakhushti Bagrationi Institute of Geography of the Ivane Javakhishvili Tbilisi State University, Tbilisi, Georgia, elene.salukvadze@tsu.ge
} 
on the south by Tskaltubo, Tkibuli, Chiatura and Sachkhere municipalities. Its area is 1142 $\mathrm{km}^{2}$.

The region occupies the southern slopes of the folded mountains of the Caucasus. It is mainly built of Jurassic and Cretaceous shale, sandstone, limestone, marl, Tertiary gypsum clay. The relief is mainly of middle and high mountain-ravine type. The southeastern and south-western boundary is stretched along the Racha Ridge, the northern slope of which is located in Ambrolauri Municipality. In the north it is bounded with the Lechkhumi Ridge (with the peaks of Samertskhle - 3584 m, Kareta - 3354 m, Lukhunistsveri $-3216 \mathrm{~m})$. In the east the ridge divides the basins of the rivers Lukhunistskali and Sakaura. In the west there are the ramifications of the Lechkhumi Ridge and the Racha Ridge. The lowest part of the municipality is occupied by Racha (Ambrolauri) Depression, the average height of the bottom of which is $500 \mathrm{~m}$. Together with tectonic and erosive processes the Quaternary glaciation has played significant role in the formation of the relief. Ancient glaciers and glaciation tracks (kars, cirques, etc.) have survived on the high ridges.

On its small territory one can meet eye-catching deciduous and coniferous forests, mountains covered with subalpine and alpine meadows, deep river gorges, karst and cultural landscapes. Racha is a region with many mountains and shortage of lands. The most part, $78.8 \%$, of its territory is occupied with mountains and foothills. Due to the relief complexity, extreme disintegration and strong inclination (48\% of the territory is covered with slopes inclined by $20^{\circ}$ and more) the resources of the land for agricultural activities are extremely limited. The agricultural lands occupy 15946 ha, which is $14 \%$ of the whole territory.

Among the mineral resources discovered in Ambrolauri Municipality are coal, arsenic (extraction is stopped), manganese, clay, antimony, limestones, etc.

For revealing and analyzing a region it is important to have climate and agroclimate characteristics and agro-industrial soil data.

The climate of Kvemo Racha varies from subtropical to continental. The air temperature sharply changes together with height variation. In the lower zone the climate is humid. Moderately cold winter and long-term warm summer is characteristic of this zone.

The average monthly air temperature during warm periods in the $300-600 \mathrm{~m}$ zone varies from $21.1^{\circ}$ to $9.5^{\circ}$ and in the $1650-200 \mathrm{~m}$ zone it is $13.8^{\circ}-1.5^{\circ}$. During cold periods the temperatures here are $7.8^{\circ}-1.0^{\circ}$ and $0.3^{\circ}--6.9^{\circ}$, correspondingly. During active vegetation period the quantity of the precipitation varies from $570-700 \mathrm{~mm}$ to $935-1220 \mathrm{~mm}$. The number of the days with snow cover is $40-170$. The maximum thickness of snow cover is $190 \mathrm{~cm}$. In the lower zone, active vegetation process starts from 4-19 April and ends at the end of the third decade of October and the beginning of November. In separate years, when freezing period lasts too long or starts in early autumn, the vegetation period may decrease by 1 month (Gobejishvili, 2000; Scientific and Applied Climate. . ., 2004).

Kvemo Racha, according to agro-climate zoning, belongs to the moderately humid region of the West Caucasus sub-district of West Georgian district (see the table below).

Kvemo Racha is rich in rivers, the main river Rioni, which flows for $40 \mathrm{~km}$ on the territory of Ambrolauri municipality and almost divides in the middle. The left tributaries 
of the Rioni River are - Krikhula, Znakvura, Sharaula, the right tributaries - Ritseula, Lukhunistskali, Askistskali and etc. Relatively large lakes are Cheliagele and Nakarevi (Satsurblia), Shaori Reservoir (area $9.2 \mathrm{~km}^{2}$ ). The reservoir is for hydropower purposes, as well as for tourist-recreational purposes. Surface and groundwater are used to supply water to the population. There are multiple mineral water sources - Uravi, Chrebalo, Abanoeti, Gorisubani, Likheti and Khidikari.

Table 1. Agro-climate characteristics of Kvemo Racha

\begin{tabular}{|c|c|c|c|c|c|c|}
\hline Object & $\begin{array}{c}\text { M. above } \\
\text { sea level } \\
\text { (m) }\end{array}$ & $\begin{array}{l}\text { The sum of active } \\
\text { temperatures }\left(10^{\circ}>\right)\end{array}$ & $\begin{array}{c}\text { Absolute minimum } \\
\text { temperature } \\
\text { (average) } \\
\left(\mathrm{C}^{0}\right)\end{array}$ & Moisture r & $\begin{array}{l}\text { te Annual sum of } \\
\text { atmospheric } \\
\text { precipitation } \\
\text { (mm) }\end{array}$ & $\begin{array}{l}\text { Duration } \\
\text { of frost- } \\
\text { free days }\end{array}$ \\
\hline Ambrolauri & 544 & 3500 & -18 & 1.2 & 1000 & $244-165$ \\
\hline Chrebalo & 530 & 3200 & -16 & 1,5 & 1034 & $250-172$ \\
\hline Khvanchkara & 560 & 3200 & -16 & 1.3 & 1150 & $254-174$ \\
\hline
\end{tabular}

(Agroclimatic resources of Georgia, Leningra, Gidrometeoizdat, 1978; Scientific and Applied reference book of climate in Georgia, 2004).

Among the soils humus-carbonate soil is dominating here. It has developed on the eroded products of limestone, marl and carbonate sandstone and limestone deluvium. Vast massifs of this kind of soil are spread over the left side of the river Rioni between villages Tsesi and Sori. In the mountainous zone there are dark grey forest soil and dark grey podzolic soil covering large areas. There is mountain-meadow land in the subalpine and alpine zone and alluvial soil on the lower terraces of the Rioni ravine. Conditions are favourable for development of viticulture and horticulture on the ravines and slopes, which are occupied with alluvial and humus-carbonate soils.

Among vegetation covers, in economical viewpoint, a forest cover is the most significant. It has soil-conserving, anti-erosion, and at the same time recreational function, which is very important for healing. The forest area occupies $50 \%$ of the whole territory of Kvemo Racha. The subalpine and alpine meadow vegetation cover is presented mostly as high-productive livestock food.

In the lower part of the ravines of the region there are Colchian forests with evergreen undergrowth. Beech forests are dominating on the lower slopes of mountains. Mixed forest of hornbeam, chestnut, oak and maple trees are also met. The undergrowth is presented with hazel nut, hawthorn, medlar, azalea, etc. There are many kinds of wild fruits in the forest: wild pear, crab apple, chequer, guelder-rose and bilberry. In high-mountain areas coniferous forests are distributed. Here and there yew trees (Taxus baccata) are met. Higher on there are subalpine and alpine meadows.

Among the animals West Caucasian tur, roe deer, wolf, bear, fox, badger, wild cat, rabbit, Caucasian squirrel, rarely lynx are found, Caucasian grouse lives in high mountains, there are many quail, owl, etc. From reptiles there are snakes, lizards, toads, lake frogs, trout and barbel -- in the rivers.

In the 80-90-ies of the past century the area of arable lands considerably decreased that was caused by following factors: as a result of the partial land reform, in regards with privatization of public lands, the infertile lands were abandoned. Due to 
significant steepness of the relief and erosive and landslide processes certain part of arable lands lost their fertility and are used for different functions nowadays.

Especially favourable agro-climatic conditions in Kvemo Racha provide development of viticulture, horticulture, cereal farming, which has been carried out by the population from ancient times.

Racha is homeland of nearly 50 species of vine. In Georgia vine mainly grows in lowlands. Among the mountainous regions of Georgia exactly the Racha ceepression is well-known for its diversity in vine species.

The endemic vine species of "Aleksandrouli", "Mujuretuli", "Tsulukidzis Tetra" and "Dzelshavi" are represented here. The yield area is spread over metric tons/ha. From these unique vine species world-wide known wines are produced. The vineyards mainly grow in the lower zone on the slopes along the river Rioni and its tributaries. The whole area of vine growing is approximately 900 ha. The vine species here are characterized with high sugariness and corresponding acidity and are distinctly different from one another for their fragrance, colour and softness. From them wellknown semisweet and table wines are produced: "Khvanchkara", "Usakhelouri", "Tetra" and "Barakoni". At different exhibitions these wines have won several gold and silver medals.

According to vertical zoning, industrial vineyards are mainly grown at height of $600-800 \mathrm{~m}$ above sea level. The extreme limit of vertical distribution is $1100-1200 \mathrm{~m}$ (Chkhartishvili, 2012).

Vineyards grow on the either sides of the gorge of the river Rioni, in the hollow surrounded by high cliffy ridges, on well-illuminated slopes that make the best thermal conditions for producing sweet and semisweet red and white wines.

The natural conditions of the zone are favourable for developing horticulture, though yield is low. The fruit of Racha is known for its taste and high quality from ancient times. Here winter and summer species of pear and apple, also quince and walnut are distributed. On small areas fig and pomegranate are met.

In Ambrolauri Municipality agricultural lands occupy 15946 ha area, which makes $14 \%$ of the whole territory, while the arable area makes 1141 ha, pastures occupy 13 108 ha and Perennial crops 1647 ha (Local Economic Develop..., 2020).

Cattle breeding is widely distributed in the municipality, though for the last years the number of broad-footed cattle has considerably decreased (by 4000 heads of livestock). The population has pigs, sheep and goats in a small quantity, is occupied with poultry-farming and bee-keeping, the development of which is well provided by diverse plants full of nectar growing in the region. Nearly whole population is involved in bee-keeping and apiculture and honey production.

There is no shortage of hay meadows and pastures for cattle-herders here. On the summer pastures 22000 cattle heads can graze, whereas 2.4 ha of hay meadows and pastures come on 1 head of cattle (Agladze, Chkheidze, 2012).The natural fodder areas of Racha are mainly located in the following vertical zones: Racha natural fodder lands are mainly located in the following vertical zones: a. the lower belt of the mountain (450-750 $\mathrm{m}$ above sea level); b. The middle belt of the mountain (750-1800 m); c. The upper belt of the mountain (subalpine meadows 1800-2400 m); $d$. The upper belt of the mountain (alpine meadows 2400-3200 m) (Fig.1) 
Ambrolauri Municipality is rich of forest resources. Here they have industrial value as well. $50 \%$ of the territory is occupied with forest, which makes 57000 ha.

Among the vegetation cover of the forests of Racha region 272 are Caucasian and Georgian endemics (among them 54 are Georgian and 9 are Racha-Lechkhumian endemics) (Kandelaki, 2012). The diversity and distinguishability of the flora is caused due to its existence in the contact zones of the geo-botanical areas of the eastern and western parts of Georgia. In Racha we meet Colchian Tertiary relicts and endemics (Pontic rhododendron, cherry laurel, bladder-nut, persimmon, box tree, etc.) as well as dry continental vegetation characteristic of the southern slope of East Georgia: oak, oriental hornbeam, hawthorn, dogwood, medlar, juniper, pine and etc. The diversity in the flora is also provided by long amplitude of heights above sea level (from $450 \mathrm{~m}$ to $4000 \mathrm{~m}$ ) and vertical zonality of vegetation distribution.

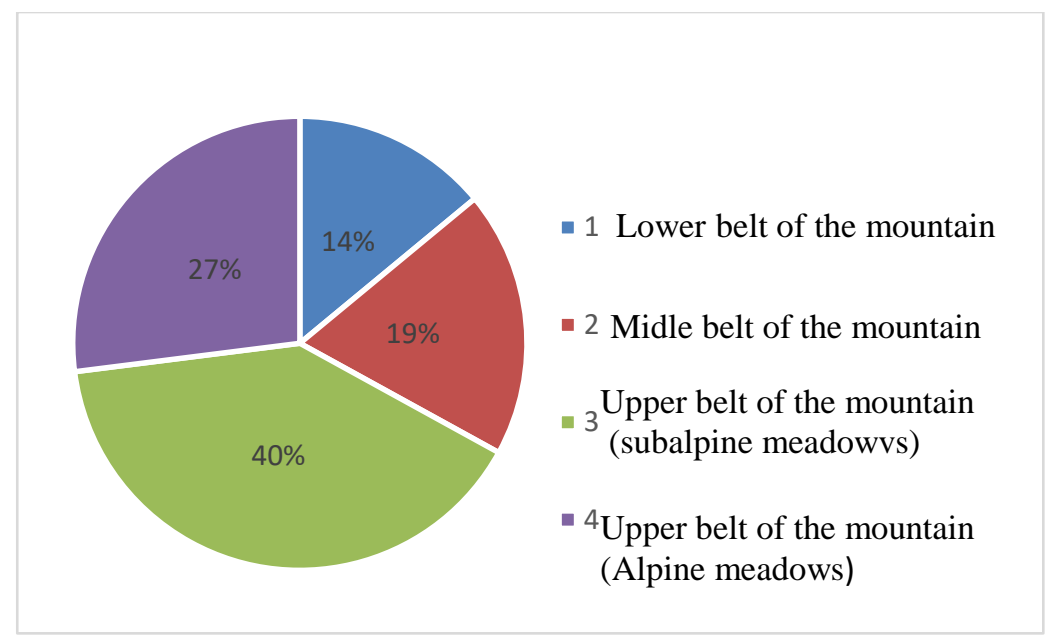

Fig.1 Structure of natural fodder lands

Here we meet all the species of coniferous plants distributed on the whole territory of the Caucasus: spruce, fir, pine, yew and juniper. Spruce and fir trees make massifs of virgin forests of high productivity in the Central Caucasus. The forests are mainly located mainly at 500-2000 m height.

Wide-leaved forests are very rich in floristic viewpoint. They are met at 1000-1100 $\mathrm{m}$ height. Here we meet oak, chestnut, beech, lime, ash, maple and other trees. Beech forests are presented as pure copses (from 1100 and above) as well as copses mixed with coniferous trees.

In the subalpine forests we meet Litvinov birch, high-mountainous maple and Caucasian rowan. Together with subalpine and alpine meadows Caucasian evergreen azalea, juniper and high-mountainous bilberry are met.

In the forest there are plants, which have entered the "Red Book" of Georgia: yew, chestnut, Colchian bladder-nut, Georgian hazel nut, sea buckthorn and etc., also the trees, which have entered in the "Red List" of Georgia: Caucasian hornbeam, Caucasian fir, black alder, oriental beech, box, oriental spruce, chestnut, highmountainous maple. 
The most forests of Kvemo Racha are located at 1001-2000 m above sea level (77.2\%). According to this the forest zonality of the region has a large diapason (450$4000 \mathrm{~m}$ above sea level) that provides diversity in the vegetation cover and clearly expressed vertical zonality. Here the whole height spectrum characteristic of West Georgia is presented.

The belt of fir and spruce copses are located at 1600-2000 $\mathrm{m}$ above sea level. The main constituent species here are Caucasian fir and oriental spruce. Here also are the timber species as beech, lime, birch, aspen and etc. The undergrowth is presented as cherry laurel, holly, bilberry, azalea, butcher's broom, daphne and others are met. The Caucasian fir tree recognized world-wide as a unique species is distributed in this zone (Fig 2).

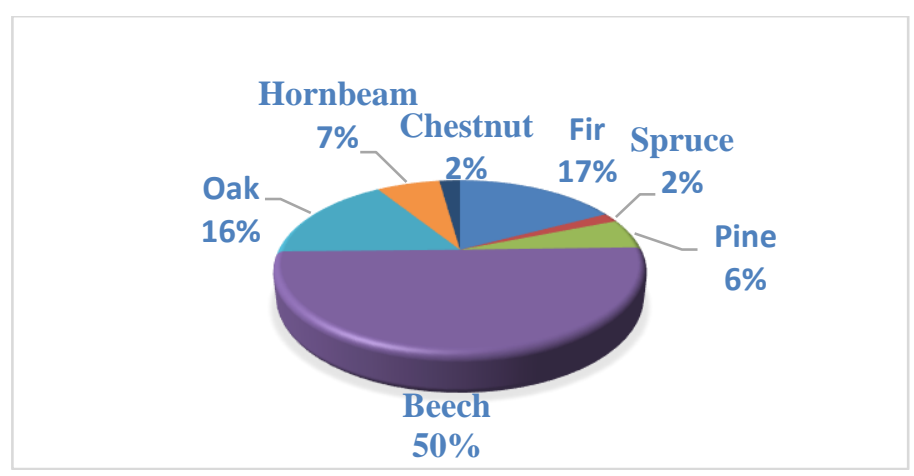

Fig. 2. Dominant woody species of Kvemo Racha forests

Racha is a region rich in forests, though is characterized with not quite high yield class indices. The most area of the Ambrolauri forests belong to yield class III and covers 25310 ha, i.e., $43 \%$ of the whole forest area. High, $\mathrm{I}^{\mathrm{a}}$ and I yield class forests occupy extremely small area in the region -1031 ha, i.e., $2.0 \%$.

The forests of Racha are characterized with considerably high density, the average value of which is 0.685 , whereas the forests of Kvemo Racha have density index 0.67. Here the dominating species are characterized with the following densities: fir -0.68 , spruce -0.63 , pine -0.61 , beech -0.69 , oak -0.68 and etc. (Kandelaki, 2012). The most part of the Ambrolauri forest are located on slopes with 20-30 inclination.

The forested area of Kvemo Racha (Ambrolauri Municipality) makes 50\% of the whole territory. This value is higher than the one of Upper Racha and the value of the whole country as well, as far as the forested area of Georgia makes $40 \%$ of the whole territory of the country. The average supply per 1 hectare of the Ambrolauri forests is $249 \mathrm{~m}^{3}$ (the one of Georgia is $161 \mathrm{~m}^{3}$ ).

The recreational potential of Kvemo Racha is of high significance - coniferous forests, favourable climatic conditions (long duration of sun light, short amplitudes of the temperatures of day and night), hydro-mineral resources (high quality mineral waters). Abundance in natural, historical, ethnographic, cultural monuments, natural monuments - karst caves in Gogoleti, Tsakhi, Tskhrajvari, Sakinule (Nikortsminda) and etc., the Shaori Reservoir make favourable conditions to develop tourism here. The region also has balneo-climatic resort Bugeuli and balneological resort Khidikari. The places with resorts potential are Uravi and Tsesigora as well.

The hypsometric difference of Kvemo Racha (Ambrolauri Municipality) between the lowest (400 $\mathrm{m}$ - the bottom of the river Rioni) and highest (3584 $\mathrm{m}$ - peak 
Samertskhle on the Lechkhumi Ridge) points, the diverse lithological structure, large number of orographic entities caused complexity and provided development of height

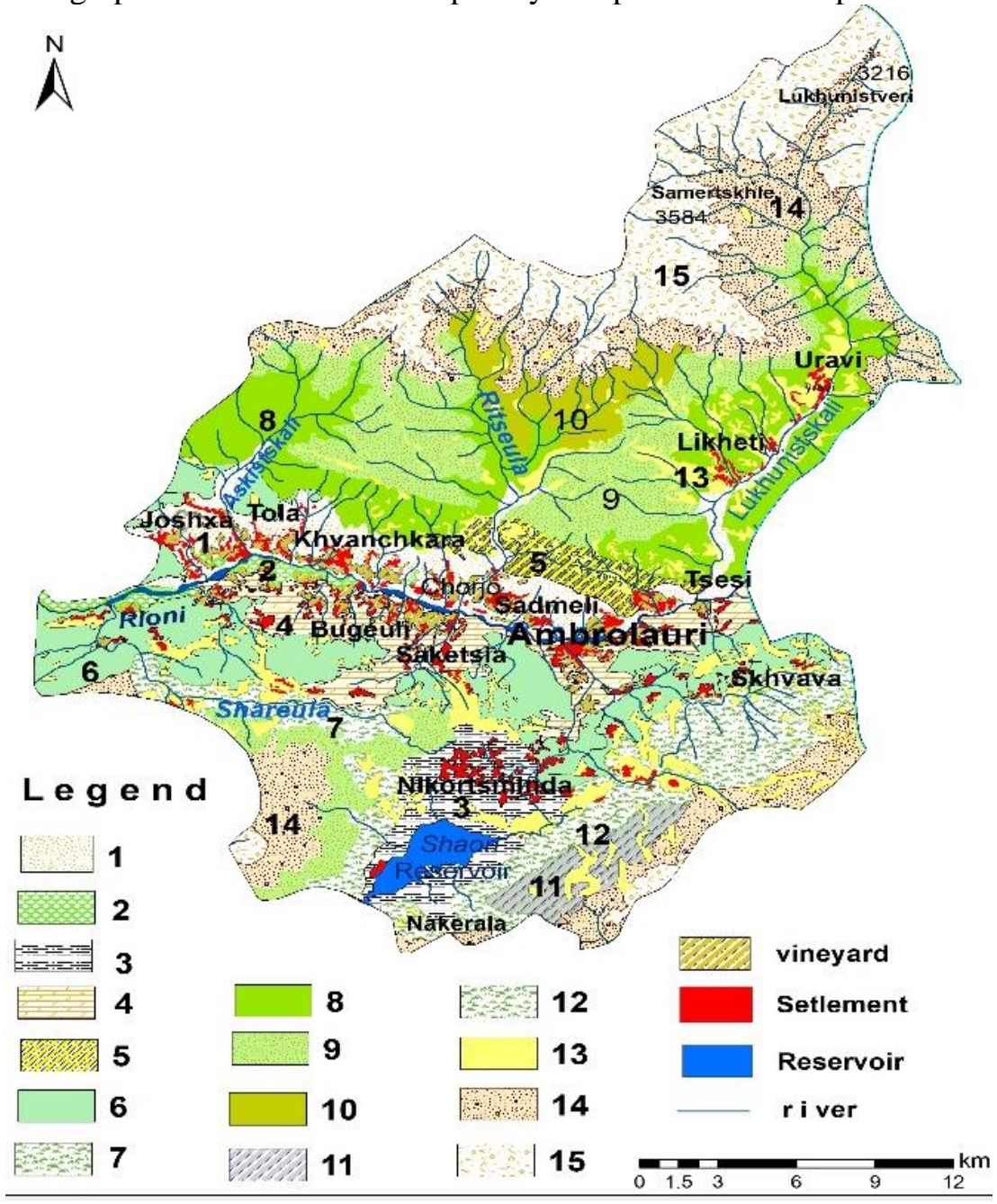

Fig. 3. Landscape map of Ambrolauri municipality

Landscapes: 1.A hollow with a synclinal river gorge, river terraces, juts at some places, humus-carbonate soil, agro-landscapes (vineyards, fruit gardens, maize fields), habitation landscapes; 2. Riverside forests with alluvial soil, inhabited landscape, agricultural land; 3. A grassy hollow between mountains with karst springs, large karst funnels, diversity in karst wells. It is used for recreation and partially, as pastures; 4 A hilly-terraced hollow, eroded relief with vast landslides, juts, agro-landscapes (vineyards, fruit gardens, arable farms) and inhabited landscapes; 5. Low mountains with steep slopes cut with gullies, shrubbery, oak forests, hornbeam forests, at some places destroyed forests and secondary meadows; 6. Low mountains, hills, eroded karst relief, at some places canyon-like ravines, significant development of erosive forms, oak and oak-hornbeam forests; 7. Low mountains with chestnut forests, at some places hornbeam forests, destroyed forests with secondary shrubbery, Colchian undergrowth; 8. Middle mountains with mountain-ravine relief, dark grey forest soil, beech and hornbeam-beech forests; 9.Middle mountains with extremely fragmented narrow and deep ravines, steep slopes, beech forests, beech-fir forests, dark grey forest soils and dark grey podzolic soils; 10. Middle mountains with fragmented erosive gorges, fir and spruce forests; 11.A plateau-like massif, short in surface rivers, with karst relief; 12. Middle mountains with high intensity of karst phenomena, karst relief, abundance in karst forms in the relief (wells, funnels, caves, etc.), at some places deep canyon-like gorges, dark grey forest soil and dark grey podzolic soil, beech-fir and fir-beech forests, Colchian undergrowth; 13. High mountains with secondary meadows in a formerly forested area; 14 . High mountains, remnants of old glaciation, with subalpine birch forests and meadow-shrublands, on mountain meadow soils; 15 . High mountains with alpine meadows, mountain-meadow soils. 
zones of the landscapes. The existence of The Racha-Lechkhumi syncline in Neogene played a great role in the peculiarity of the formation of the relief. It caused the existence of the Racha Depression, which has a lowland and hilly relief surrounded with middle and high mountains.

We carried out comprehensive studies of landscapes on the territory of the region in regards to landscapes. Each type of distinguished landscapes is estimated in the viewpoint of their natural conditions and potential possibility of resource usage. On the territory of Ambrolauri Municipality we distinguished 15 types of landscapes. We will consider several out of these landscapes as far as they have significant resource potentials (Fig. 3):

1. A hollow with a synclinal river gorge, river terraces, juts at some places, humuscarbonate soil, agro-landscapes (vineyards, fruit gardens, maize fields), habitation landscapes. This kind of landscape is located in synclinal Racha Depression. The relief is the widened segment of the right bank of the Rioni gorge. It is fragmented with fluvial terraces. Landslides and juts are observed here. This is a zone of an agricultural settlement and active economic activities. The quantity of annual precipitation is 1000-2000 $\mathrm{mm}$. The vegetation period lasts for 7 months. The average air temperature in July and August is $22^{\circ}$. High summer temperatures are caused by the cavity form of the relief and foehn winds. The active temperature sum during the vegetation period is 2600-3900. The average annual duration of sun light is 1900-2000 hours. The humus-carbonate soil on the right side of the river Rioni has mostly developed on the eroded crust of carbonate sandstones. The average thickness of soils is $40-60 \mathrm{~cm}$. The humus capacity is $8-9 \%$. The natural vegetation cover has considerably changed due to high population density and economic activities. Only separate copses of forest derivates have survived.

Within the boundaries of the landscape the vineyards grown in the specific viticulture microzones of Kvemo Racha (the southern slopes of the Lechkhumi Ridge) produce such famous wines as "Khvanchkara", "Usakhelouri", Tetra', "Arabeuli" and etc. The micro-zone is located at 450-750 $\mathrm{m}$ above sea level, on the right bank of the river Rioni, in the hollow surrounded by high ridges. It includes the following villages: Khvanchkara, Chrebalo, Tola (I and II), Chorjo, Sadmeli and Bostana. Among the vine species, according to growing area, "Aleksandrouli", "Mujuretuli" and "Tsolikauri" occupy the first place. Then come "Kapistoni", "Sapheravi" and etc. The climate is moderately warm and humid. During vine ripening period the climate is dry and sometimes drought-stricken, the quantity of precipitation considerably decreases that cause high sugariness in the vine.

The natural fodder lands are distributed on the lowlands and hills along the river Rioni and its tributaries - the pastures at village edges, the grass cover of which is presented as dry, feral meso-xerophilous groups. Among them wild sorghum, brome and quaking-grass are dominating.

2. Riverside forests with alluvial soil, inhabited landscape, agricultural lands. The landscape is distributed alongside the river Rioni. It includes riverside forests composed of aspen, willow and alder trees. In regards to economy it is the best territory for maize, wheat, vegetable and fruit.

3. A grassy hollow between mountains with karst springs, large karst funnels, diversity in karst wells. It is used for recreation and partially, as pastures. The Shaori hollow is located between the Nakerala Ridge and village Nikortsminda. The slopes of Nakerala and Racha ridges, which are adjacent to the Shaori Hollow, are rich in karst funnels and wells. 
Here are the caves of Sakinule (to the village of Nikortsminda) and Sakishore (To the village of Tlughi). Pastures occupy a vast territory. Here cereals are dominating.

4. A hilly-terraced hollow, eroded relief with vast landslides, juts, agro-landscapes (vineyards, fruit gardens, arable farms) and inhabited landscapes. This landscape is located in synclinal Racha Depression. The relief is the widened segment of the left bank of the river Rioni. The relief is fragmented with fluvial terraces. Here landslides are frequent (strong landslides are observed in the areas of Mukhli, Khimshi, Saketsia, Shroma, Kveda Shavra, Bugeuli, Baji). There are sharp bends on the left tributaries (river Khoteura, river Znakvura, etc.) of the river Rioni. It is an active rural and economic zone.

Within the boundaries of the landscape on the left bank of the river Rion located viticulture micro-zone of Ambrolauri -Bugeuli. With main villages: Ambrolauri, Bugeuli, Saketsia, Bareuli, Gadishi, Abanoeti, Tsesi, Khimshi. The micro-zone is located at 500-800 m above sea level, on the left bank of the river Rioni.

This area is quite different, with its exposition and soils, from the territories on the right bank of the river Rioni located opposite to it. Here vineyards are growing on northern and north-eastern slopes. The vineyards are shaded for several hours (at least two hours) a day by the mountains at their south and south-east. It makes a negative influence on the intensity of sugar accumulation in vine. Therefore, this micro-zone gives moderate quality red dry wines. Here mainly white species grow: "Tetra", "Kudurauli (sugariness - 20-23\%), "Khikhvi”, "Tsulukidzis Tetra", "Tetri (white) Kapistoni”, "Tetri (white) Arabeuli”. They give better quality wines then the red species do.

5. Low mountains with steep slopes cut with gullies, shrubbery, oak forests, hornbeam forests, at some places destroyed forests and secondary meadows. The landscape is located on the Saelio Ridge, between the villages of Kvatskhuti and Tsesi, from the river Ritseula to the lower flow of the river Lukhunistskali at height 1000-1300 m above sea level. The precipitation quantity varies from $950 \mathrm{~mm}$ to $1300 \mathrm{~mm}$. Among the soils dark grey forest soil is dominating. The vegetation cover consists of oak forests, hornbeam-oak forests and hornbeam forests. At some places the forests have been cut down and replaced with secondary meadows.

6. Low mountains, hills, eroded karst relief, at some places canyon-like ravines, significant development of erosive forms, oak and oak-hornbeam forests. The landscape includes the slopes of the Racha Ridge. Surroundings villages: Skhartali, Tskadisi, Khotevi, Skhvava At some places the oak forests have degraded and replaced with oak and oriental hornbeam trees. Large areas are occupied by inhabited localities and agricultural lands. It is possible to run pig farms here as far as the oak forests give the best food for them. 7. Low mountains with chestnut forests, at some places hornbeam forests, destroyed forests with secondary shrubbery, Colchian undergrowth. The landscape is distributed in the Nakerala-Shaori area at $1500 \mathrm{~m}$ above sea level. The natural vegetation cover of this belt is presented with chestnut forests. Extremely steep slopes rich in limestone soils are covered with Georgian oak copses. In the forest are mainly found hornbeam, beech, pine, maple, yew trees, common bladdernut, wild pear, crab apple, dogwood, guelder-rose and bilberry.

8. Middle mountains with mountain-ravine relief, dark grey forest soil, beech and hornbeam-beech forests. The belt of beech forests is met from $1000 \mathrm{~m}$ to $1600 \mathrm{~m}$ above sea level. The main timber species composing the forest here is oriental beech, which is mixed with hornbeam, chestnut, lime, fir, spruce and aspen trees. in the undergrowth blackberry, Pontic rhododendron, hazel nut, bilberry and etc. 
9. Middle mountains with extremely fragmented narrow and deep ravines, steep slopes, beech forests, beech-fir forests, dark grey forest soils and dark grey podzolic soils. The forests within the boundaries of the landscape bring considerable benefits to the population - wood is the main raw material used by them for heating. Besides, the population receives high income from collecting the seeds of Caucasian fir-tree (it is exported to Europe). Among the non-timber plants of the forest the population uses wild fruit and berries such as wild pear, dogwood, dog rose, chestnut, fir seeds, hawthorn, sea buckthorn and etc. Great quantity of healing plants is met here: marjoram, southernwood, St John's wort, valerian, yarrow, greater celandine, chicory and etc. There are also a great number of plants, which are the best for development of apiculture. The honey produced here is distinguished for its high quality and is ecologically clean. The belt of fir copses is spread from $1600 \mathrm{~m}$ to $2000 \mathrm{~m}$ above sea level. Its main constituent species is Caucasian fir tree. Precipitation quantity makes $1500 \mathrm{~mm}$ that provides distribution of best massifs of dark coniferous forest with well-developed Colchian undergrowth.

10. Middle mountains with fragmented erosive gorges, fir and spruce forests. The landscape is located on the ridges of Svanebi and Kekhitekho, in the gorges of Ritseula and Sokhasteri. The spruce forest belt occupies the area from $1600 \mathrm{~m}$ to $2000 \mathrm{~m}$ above sea level. Its main constituent species is oriental spruce, which is mixed with beech, lime, birch, aspen and other timber species.

11. A plateau-like massif, short in surface rivers, with karst relief. The landscape is located on the Nakerala Ridge. Here lightly erosive and karst processes are observed, with forms characteristic for it, funnels, wells. It is only slightly fragmented with rivers that can be explained by the intensive karst development.

12. Middle mountains with high intensity of karst phenomena, karst relief, abundance in karst forms in the relief (wells, funnels, caves, etc.), at some places deep canyon-like gorges, dark grey forest soil and dark grey podzolic soil, beech-fir and fir-beech forests, Colchian undergrowth. The landscape is spread over the eastern part of the Nakerala Ridge. The belt of beech forest is located from $1000 \mathrm{~m}$ to $1600 \mathrm{~m}$ above sea level. The main component of the forest among timber species is oriental beech tree. Humidity rate on the Nakerala Ridge is the highest in whole Racha. The quantity of precipitation is also registered as the greatest $(2000 \mathrm{~m})$. Its high value causes development of Colchian undergrowth and intense formation of Pontic rhododendron in karst hollows, which form impenetrable thorny undergrowth known as so called "Shkeriani".

13. High mountains with secondary meadows in a formerly forested area. The landscape is located on the Lechkhumi Ridge (to the north) and on the Racha Ridge (to the south). The meadows are of secondary origin. They have formed as a result of cutting down of forests and cattle grazing, which prevents the forest from restoration. There are rockslide and landslide foci at some places.

14. High mountains, remnants of old glaciation, with subalpine birch forests and meadow-shrublands, on mountain meadow soils. The landscape is spread over the southern slopes of the Lechkhumi Ridge at 2000-2300 m above sea level, upstream of rivers Aski, Ritseula, Zhrinevi and Lukhuni. These landscapes are characterized by intense erosion and denudation processes, rock falls, mudflow processe. Litvinov birch, highland maple, Caucasian rhododendron are found in subalpine forests. Subalpine belt meadows are suitable for livestock and are used as natural pastures.

15. High mountains with alpine meadows, mountain-meadow soils. In the alpine zone, the vegetation is represented mainly by grass groups, suitable for natural food in the form 
of livestock. The landscapes in the high-mountainous subalpine and alpine zones in the Kvemo Racha are the best pastures and meadows for mowing that are necessary for cattle breeding.

\section{Conclusion}

As a result of comprehensive studies of Kvemo Racha by GIS technology a largescale landscape map (1:50 000) of Kvemo Racha (Ambrolauri Municipality) region was constructed. We distinguished 15 low rank landscape entities - landscape types. The distinguished landscapes give a clear image of the diversity and potential of the natural resources of the study region. It is noteworthy that the most part (78.8\%) of the landscapes is made of mountain landscapes. Certain part of the distinguished landscapes is useful for agricultural activities; some part can be used as forest resources and the other part - for tourism and recreation aims.

The most part of the agricultural landscapes is located in considerably lower hypsometric zone (400-800 m) in synclinal Racha Depression, on either sides of the river Rioni. The landscapes (\#1, \#4) here have a special role in the development of viticulture in Kvemo Racha. The majority of vineyards of Racha (900 hectares from 1028 hectaremsd@ృбo@s6) are located here. The landscapes (\#2) on the alluvial soils along the river Rioni are the most useful for fruit and vegetable growing and cereal farming. The landscapes in the Shaori Hollow (\#3) and high-mountainous subalpine (\#14) and alpine (\#15) zones are the best pastures and meadows for mowing that are necessary for cattle breeding, the total area makes 24000 ha. The pastures and hay meadows of Kvemo Racha have great potential. They can provide development of livestock breeding here. The forest landscapes occupy the mort territory of Kvemo Racha. They have high value in industry as well as in preserving ecology and biodiversity. Here the landscapes of river-side forests (\#2), low mountain forests ( $\# 5$, \#6, \#7 landscapes) and middle mountain forests (\#8, \#9, \#10, \#11) are met. Among them virgin forests occupy quite a considerable area. Great touristic and recreational potential has been unlocked in the landscapes (\#3, \#6) around the Shaori Reservoir, the landscapes where karst caves, balneo-climatic (Bugeuli) and balneological (Khidikari) resorts, also resort places (Uravi and Tsesigora) and other significant tourism and recreation objects are located. Among the landscapes of Kvemo Racha the ones in Racha Depression, the boundary landscapes of low mountains, middlemountainous forests and high-mountainous meadows have changed. At many places secondary meadows can be observed at the places of former forests. The natural landscapes existing in the past here are presented as varieties of anthropogenic and natural-anthropogenic landscapes.

\section{References}

Agladze Gogotur, Phiran Chkheidze (2012). Rach'is sadzovrebis mdgomareoba, mati produktiulobisa da khariskhis gazrdis ghonisdziebebi//n: Rach'a: ts'arsuli, ats'mq'o, momavali/Sakartvelos metsnierebata ak'ademiis mtis problemebis k'ompleksuri shests'avlis k'omisia. [Condition of Racha pastures, measures to increase their productivity and quality]//n: Racha: Past, Present, Future/Commission for Complex Study of Mountain Problems of the Georgian 
National Academy of Sciences, Tbilisi: Georgian National Academy of Sciences Press, 117-127; (in Georgian)

Agroklimatičeskie resursi Gruzii (1978), Agroclimatic resources of Georgia] Leningrad, Gidrometeoizdat, p. 78-124.

Chkhartishvili Nodar (2012). Mevenakheobisa da meghvineobis ganvitarebis problemebi Rach'ashi// In: Rach'a: ts'arsuli, ats'mq'o, momavali/Sakartvelos mets'nierebata ak'ademiis mtis problemebis k'ompleksuri shests'avlis k'omisia. [Problems of development of viticulture and Winemaking in Racha]//n: Racha: Past, Present, Future/Commission for Complex Study of Mountain Problems of the Georgian National Academy of Sciences /Georgia, Tbilis: Georgian National Academy of Sciences Press, p. 153-160; (in Georgian)

Gobejishvili Ramin (2000). Rach'a-Lechkhumi//n: Sakartvelos geograpia, nats'ili I, Pizik'uri geograpia - Racha-Lechkhumi//n: Geography of Georgia, Part I, [Physical Geography of Georgia], Tbilisi: Metsniereba, 259-260 p.; (in Georgian)

Kandelaki Teimuraz (2012). Rach'is regionis tq'is resoursebi//In: Rach'a: ts'arsuli, ats'mq'o, momavali/Sakartvelos metsnierebata ak'ademiis mtis problemebis k'ompleksuri shests'avlis k'omisia. [Forest resources of the Racha region]/In: Racha: Past, Present, Future/Commission for Complex Study of Mountain Problems of the Georgian National Academy of Sciences/Georgia, Tbilis: Georgian National Academy of Sciences press, p. 271-276; 283-2 87 (in Georgian)

Ambrolauris municipalitetis ekonomikuri ganvitarebis gegma - [Local Economic Development Plan Ambrolauri Municipality] (2020). Georgia, Ambrolauri: http://ambrolauri.gov.ge/geo_version.pdf, 14-15 p.; (in Georgian)

Garemos mdgomareobis shesakheb erovnuli angarishi 2014-2017 ts'listvis. [National Report on the State of the Environment for 2014-2017]/30.12/2019, Georgia, Tbilisi (in Georgian)

Saneblidze, Meliton, David Ukleba, Christephore Jakeli (1970) Sakartvelos Landshapturi ruk'a. [Landscape Map of Georgia (1: 600 000)], Tbilisi-Moscow: Main Department of Geodesy and Cartography/Russia, Moscow: (in Georgian).

Sakartvelos samets'niero da gamoq'enebiti ts'nobari. [Scientific and applied reference book of climate in Georgia], (2004), Part I., Tbilisi: Bakur Sulakauri Publishing, p. 55-82; (in Georgian)

Ukleba David, Budag Budagov, Museib Museibov, Elena Sokhadze, Aleksandr Bagdasarov (1983), Landšaftnaja karta Zakavkazija, Glavnyi departament geodezii i kartografii - [Landscape map of the South Caucasus, (1: 600 000)], Main Department of Geodesy and Cartography/ Russia, Moscow: (in Russian) 